\title{
PERBEDAAN PENGETAHUAN IBU YANG MEMILIKI ANAK USIA 1-2 TAHUN SEBELUM DAN SETELAH DIBERIKAN PENYULUHAN TENTANG PENYAPIHAN ASI DI POSYANDU
}

\section{(Desa Bobang Kecamatan Semen Kabupaten Kediri)}

Yunda Dwi Jayanti, S.ST.M.Keb 1, Irvin Sukmawati 2

Akademi Kebidanan Dharma Husada Kediri

\begin{abstract}
ABSTRAK
Penyapihan adalah suatu proses yang memungkinkan bayi dapat mengonsumsi makanan orang dewasa. Biasanya ibu-ibu khususnya di pedesaan tidak mengetahui bagaimana proses dan waktu yang tepat dalam proses penyapihan. Tujuan penelitian adalah mengetahui Perbedaan Pengetahuan Ibu Yang Memiliki Anak Usia 1-2 Tahun Sebelum dan Setelah Diberikan Penyuluhan Tentang Penyapihan ASI

Desain penelitian ini adalah penelitian one group pre post test design dengan populasi semua ibu yang memiliki anak usia 1-2 tahun. Teknik sampling yang digunakan adalah total sampling. Sampel yang digunakan 35 responden. Variabelnya penyuluhan tentang penyapihan ASI dan pengetahuan ibu tentang penyapihan ASI sebelum dan setelah diberikan penyuluhan. Pengumpulan data dengan kuesioner selanjutnya data di olah dengan editing, coding, scoring, tabulating, dan di uji dengan Willcoxon Match Pair Test.

Hasil pengetahuan ibu sebelum diberi penyuluhan adalah dari 35 responden yang diteliti didapatkan 25 responden $(52,1 \%)$ sebagian besar mempunyai pengetahuan kurang. Dan setelah diberikan penyuluhan dari 35 responden yang diteliti didapatkan 25 responden $(52,1)$ mempunyai pengetahuan cukup. Menurut hasil uji beda Willcoxon Match Pair Test didapatkan nilai Z hitung > dari $\mathrm{Z}$ tabel $(5,16>1,96)$, maka $\mathrm{H}_{1}$ diterima .

Berdasarkan hasil penelitian tersebut dapat disimpulkan bahwa ada perbedaan pengetahuan ibu yang memiliki anak usia 1-2 tahun sebelum dan setelah diberikan penyuluhan tentang penyapihan ASI. Oleh karena itu, diharapkan tenaga kesehatan memberikan penyuluhan tentang penyapihan ASI dan bagi responden hendaknya mendapatkan informasi penyapihan ASI baik melalui media massa, media elektronik maupun tenaga kesehatan.
\end{abstract}

Kata Kunci : Pengetahuan, Ibu, Anak Usia 1-2 Tahun, Penyuluhan, Penyapihan ASI, V Bab, 97 Hal, 4 Tabel, 6 Gambar, 17 Lampiran, 26 Daftar Pustaka 


\section{PENDAHULUAN}

Sejak seorang wanita memasuki kehidupan keluarga padanya harus sudah tertanam suatu keyakinan kalimat "saya harus menyusui bayi saya" karena menyusui adalah realisasi dari tugas yang wajar dan di mulai dari seorang ibu.Air Susu Ibu (ASI) merupakan makanan utama bagi bayi, yang sangat dibutuhkan olehnya terutama 6 bulan pertama yang sering disebut ASI eksklusif (Prasetyono, 2009: 15).ASI mengandung nutrisi yang lengkap untuk perkembangan si kecil dan melindungi pencernaan si kecil dari bakteri.Karena itu, berikan ASI sejak si kecil lahir hingga 2 tahun untuk membekalinya dengan nutrisi yang baik (Nakita, 2008).

Setelah ASI eksklusif, bukan berarti pemberian ASI dihentikan.Seiring dengan pengenalan makan kepada bayi, pemberian ASI tetap dilakukan.Sebaiknya menyusui 2 tahun menurut rekomendasi WHO (Fitria, 2007: 349). ASI sebagai makanan tunggal akan cukup memenuhi kebutuhan tubuh bayi normal sampai usia 6 bulan. Setelah usia 6 bulan, bayi harus mulai diberi makanan padat, tetapi ASI dapat diteruskan sampai usia 2 tahun.(Roesli, 2005:17).

Biasanya ibu-ibu khususnya di pedesaan tidak mengetahui bagaimana proses dan waktu yang tepat dalam proses penyapihan. Pada umumya mereka melakukan proses penyapihan secara mendadak tanpa memikirkan psikologis anak. Apalagi untuk ibu-ibu yang pada umumnya bekerja sebagai wanita karir atau bekerja di pabrik tidak memiliki cukup waktu untuk menyusui anaknya sehingga secara tidak langsung melakukan penyapihan sebelum waktunya atau penyapihan dini.Ditegaskan dalam Al Qur'an surat Al Baqarah ayat 233 dianjurkan agar para ibu memberi ASI sampai bayi berusia 2 tahun. "Para ibu hendaklah menyusukan anak-anaknya selama 2 tahun penuh, yaitu bagi yang ingin menyempurnakan penyusuan" (Al Qur'an, 2003: 57).

Penyapihan (Weaning) adalah suatu proses yang memungkinkan bayi dapat mengonsumsi makanan orang dewasa. Pada masa penyapihan, makanan anak mengalami perubahan secara perlahan, yakni dari ASI menjadi campuran antara ASI dan makanan lain yang berbentuk padat (Prasetyono, 2009: 198). Proses penyapihan dianggap selesai bila anak sepenuhnya tidak lagi tergantung dari air susu ibu (Wikipedia, 2013). Proses tersebut dapat disebabkan oleh berhentinya anak dari menyusu pada ibunya atau bisa juga berhentinya ibu untuk menyusui anaknya. Masa menyapih sendiri merupakan pengalaman emosional bagi ibu, anak juga ayah. Karena 3 pihak tadi merupakan ikatan kesatuan yang tidak akan terlupakan (Fitria, 2007: 353).

Dalam kehidupan bayi, permulaan proses penyapihan merupakan awal perubahan besar bagi bayi dan ibu. Pada masa kehamilan dan paskakelahiran, hubungan ibu dan bayi sangat erat. Saat proses penyapihan, hubungan tersebut berangsur-angsur melemah. Oleh sebab itu, bila ibu menghentikan pemberian ASI secara tiba-tiba, maka kondisi psikologis dan gizi bayi terganggu (Prasetyono, 2009: 198).Selama masa penyapihan, bayi seringkali menderita berbagai penyakit seperti batuk dan diare karena reaksi dari sistem imun.Menyapih perlahan lebih baik bagi payudara dan kesehatan fisik dan psikologis bayi anda. Semakin mendekati akhir menyusui, kadar faktor kekebalan tubuh dalam ASI meningkat. Ini sangat penting karena anak akan mulai lebih sering kontak dengan kuman dan virus seiring dengan semakin banyak kegiatannya. Penyapihan akan lebih mudah jika anda dan anak siap untuk itu. Ada anak yang tidak mau disapih dan sangat gusar jika tidak disusui karena sangat menyukai saat istimewa dan perhatian yang mereka dapatkan selama menyusu (Cox, 2006: 191). Jangan menyapih dengan cara meninggalkannya. Pelepasan kedekatan emosional dari payudara ibu dan keseluruhan peran ibu secara mendadak akan menghasilkan stres yang berlebihan bagi seorang bayi. Kunci penyapihan yang sehat adalah bahwa hal ini harus dilakukan secara bertahap (Sears, 2007: 267).

Hasil penelitian yang dilakukan di Biro Konsultan Anak di Rumah Sakit UGM Yogyakarta tahun 1976 menunjukkan bahwa anak yang disusui sampai dengan satu tahun $50,6 \%$. Sedangkan data dari Survey Demokrasi Kesehatan Indonesia (SDKI) tahun 1991 bahwa ibu memberi ASI pada bayi 0-3 bulan yaitu $47 \%$ di perkotaan dan 55\% di pedesaan Depkes 1992 dari laporan SDKI tahun 1994 (Arifin Siregar, 2004).

Hasil penelitian praktek kerja lapangan Akbid UNISKA Kendal tahun 2009 
menunjukan bahwa gambaran penyapihan anak di wilayah kerja puskesmas Kendal adalah umur 0-2 tahun sebanyak 11 anak, yang disusui $<1$ tahun 7 anak dan yang disusui sampai 2 tahun 4 anak. Data Posyandu dari 14 anak, yang disusui $<1$ tahun 6 anak dan yang disusui $>1$ tahun 8 anak. Dari 10 ibu yang mempunyai balita didapatkan hasil 6 orang $(60 \%)$ berpengetahuan kurang baik tentang penyapihan, 2 orang $(20 \%)$ berpengetahuan baik, dan 2 orang $(20 \%)$ berpengetahuan cukup, (Natallisa, 2009).

Pengetahuan ibu dalam melakukan penyapihan juga dipengaruhi oleh tingkat pendidikan.Dimana sebagian besar ibu yang menyusui anaknya selama 2 tahun cenderung ibu yang terpelajar (Ramaalah, 2007). Kurangnya pemahaman Ibu mengenai proses penyapihan yang benar menimbulkan ibu melakukan penyapihan sebelum waktu yang dianjurkan. Berbagai faktor dapat mempengaruhi proses penyapihan salah satunya pekerjaan ibu. Ibu yang bekerja sebagai wanita karier cenderung memiliki waktu yang kurang dalam menyusui anaknya.Hal ini biasa terjadi di masyarakat perkotaan yang cenderung melakukan penyapihan pada umur yang lebih dini bahkan ada pula yang menyapihnya pada umur baru beberapa minggu (Hasanah, 2012:145).

Banyak ibu beranggapan jika hamil lagi ibu harus segera berhenti menyusui. Sampai saat inipun banyak anggapan bahwa jika anak terus disusui nantinya akan susah disapih. Kenyataan yang ada sering kali merancukan kedekatan orang tua dengan anak dengan manja dan kurang mandiri. Bukanlah secara psikologis pada usia tersebut anak justru membutuhkan kedekatan yang bagus dengan orang tuanya (Fitria, 2007: 353).

Hidup adalah serangkaian penyapihan bagi anak berpisah dari rahim anda, dari payudara anda, dari tempat tidur anda, dan dari rumah bila ia sekolah kelak. Ritme atau kecepatan anak bergerak, dari berada bersama anda ke keadaan terpisah dari anda, harus dicermati dalam kerangka penyapihan. Bila anda mendorong anak untuk melewati semua hubungan ini sebelum waktunya, hal itu dapat meningkatkan resiko terkena penyakitpenyakit penyapihan dini: marah, bersikap agresif, cemas, dan kurang mampu untuk membentuk hubungan yang lebih intim. Penyapihan dilakukan secara perlahan dan tepat waktu. Dalam proses berpindah dari suatu kesatuan ke situasi berpisah yang normal, bukan ibu yang menyapih bayi, melainkan si bayilah yang melepaskan diri dari ibunya. Dengan begitu, anak yang paling merasa aman, mandiri dan bahagia adalah anak yang tidak disapih sebelum waktunya (Sears, 2007: 271).

Pentingnya penyuluhan secara terpadu dari berbagai sektor baik dalam skala luas yaitu dengan melalui media cetak dan dengar, organisasi kemasyarakatan dan pemerintah, maupun dalam skala sempit di tingkat desa dengan melalui PKK yang di integrasikan dalam pelaksanaan posyandu, juga pengetahuan kader kesehatan perlu ditingkatkan dan disegarkan secara berkala agar pengetahuan mereka dapat dipakai untuk memperbaiki kekeliruan yang dilaksanakan para ibu dalam pemberian ASI sekaligus proses penyapihannya (Hasinuddin, 2010).

Berdasarkan data hasil studi pendahuluan bulan Mei 2013 di posyandu Desa Bobang Kecamatan Semen Kabupaten Kediri didapatkan 12 ibu yang memiliki anak usia 2 tahun. Dari hasil wawancara 5 orang ibu sudah mengerti tentang penyapihan dan telah menyapih anaknya pada umur 2 tahun, 7 orang ibu belum mengerti tentang penyapihan. Dari 7 orang tersebut 5 diantaranya menyapih saat anaknya berumur kurang dari 2 tahun, 2 orang lainnya belum menyapih anaknya yang berumur lebih dari 2 tahun.

Dari uraian tersebut maka peneliti merasa tertarik untuk melakukan penelitian mengenai Perbedaan Pengetahuan Ibu Yang Memiliki Anak Usia 1-2 Tahun Sebelum dan Setelah Diberikan Penyuluhan Tentang Penyapihan ASI di Posyandu Desa Bobang Kecamatan Semen Kabupaten Kediri.

\section{METODE}

Rancangan penelitian ini menggunakan Metode Pre Experimental. Hal ini sesuai dengan tujuan penelitian yaitu untuk menguji perbedaan antara satu variabel bebas dengan satu variabel tergantung. Rancangan yang digunakan yaitu one group pre post test design dalam satu kelompok dimana suatu kelompok sebelum dikenai perlakuan tertentu diberi Pre Test, kemudian setelah perlakuan berikan Post Test selanjutnya dilakukan pengukuran untuk mengetahui akibat dari perlakuan. Pengujian sebab-akibat dengan 
cara membandingkan hasil Pre Test dengan Post Test.

HASIL

a. Pengetahuan Ibu Yang memiliki Anak Usia 1-2 Tahun Sebelum di Berikan Penyuluhan Tentang Penyapihan ASI

\begin{tabular}{|c|l|c|c|}
\hline $\begin{array}{c}\text { N } \\
\text { o }\end{array}$ & $\begin{array}{c}\text { Tingkat } \\
\text { pengetahu } \\
\text { an }\end{array}$ & $\begin{array}{c}\text { Frekuensi } \\
\text { (orang) }\end{array}$ & $\mathbf{\%}$ \\
\hline 1 & Baik & 5 & $14,3 \%$ \\
\hline 2 & Cukup & 5 & $14,3 \%$ \\
\hline 3 & Kurang & 25 & $71,4 \%$ \\
\hline \multicolumn{2}{|c|}{ Jumlah } & $\mathbf{3 5}$ & $\mathbf{1 0 0 \%}$ \\
\hline
\end{tabular}

b. Pengetahuan Ibu Yang memiliki Anak Usia 1-2 Tahun Setelah Diberikan Penyuluhan Tentang Penyapihan ASI

\begin{tabular}{|c|l|c|c|}
\hline $\begin{array}{c}\text { N } \\
\mathbf{0}\end{array}$ & $\begin{array}{c}\text { Tingkat } \\
\text { pengetahua } \\
\text { n }\end{array}$ & $\begin{array}{c}\text { Frekuensi } \\
\text { (orang) }\end{array}$ & $\mathbf{\%}$ \\
\hline 1 & Baik & 10 & $28,6 \%$ \\
\hline 2 & Cukup & 25 & $71,4 \%$ \\
\hline 3 & Kurang & 0 & 0 \\
\hline \multicolumn{2}{|c|}{ Jumlah } & $\mathbf{3 5}$ & $\mathbf{1 0 0}$ \\
\hline
\end{tabular}

c. Perbedaan Pengetahuan Ibu Yang Memiliki Anak Usia 1-2 Tahun Sebelum dan Setelah Diberikan Penyuluhan Tentang Penyapihan ASI

Berdasarkan hasil uji statistic dengan menggunakan Wilcoxon Match Pair Test menunjukkan hasil $\mathrm{Z}$ hitung sebesar 5,16 dengan tingkat kemaknaan 0,025 dan nilai $Z$ tabel $=1,96$. Karena nilai $Z$ hitung lebih besar daripada $\mathrm{Z}$ tabel $(5,16>1,96)$, maka $\mathrm{H}_{\mathrm{O}}$ ditolak dan $\mathrm{H}_{1}$ diterima yang artinya ada perbedaan pengetahuan ibu yang memiliki anak usia 1-2 tahun sebelum dan setelah dberikan penyuluhan tentang penyapihan ASI di Posyandu Desa Bobang Kecamatan Semen Kabupaten Kediri.

\section{DISKUSI}

1. Pengetahuan Ibu Yang Memiliki Anak Usia 1-2 Tahun Sebelum Diberikan Penyuluhan Tentang Penyapihan ASI

Berdasarkanpenelittian didapatkan bahwa dari 35 responden pengetahuan ibu yang memiliki anak usia 1-2 tahun sebelum diberikan penyuluhan tentang penyapihan ASI 25 responden $(71,4 \%)$ memiliki pengetahuan kurang, 5 responden $(14,3 \%)$ memiliki pengetahuan cukup, dan 5 responden $(14,3 \%)$ memiliki pengetahuan baik.

Biasanya ibu-ibu khususnya di pedesaan tidak mengetahui bagaimana proses dan waktu yang tepat dalam proses penyapihan. Pada umumya mereka melakukan proses penyapihan secara mendadak tanpa memikirkan psikologis anak. Apalagi untuk ibu-ibu yang pada umumnya bekerja sebagai wanita karir atau bekerja di pabrik tidak memiliki cukup waktu untuk menyusui anaknya sehingga secara tidak langsung melakukan penyapihan sebelum waktunya atau penyapihan dini.

Menurut Elizabeth $\mathrm{BH}$ yang dikutip Nursalam (2003), usia adalah umur individu yang terhitung mulai saat dilahirkan sampai berulang tahun.sedangkan menurut Huclok (1998) semakin cukup umur, tingkat kematangan dan kekuatan seseorang akan lebih matang dalam berfikir dan yang bekerja (Wawan \& Dewi, 2010:17).

Dalam hal ini umur ibu mempengaruhi pengetahuan karena semakin cukup umur kemampuan dalam berpikir seseorang akan semakin matang sehingga seseorang yang lebih tua usianya cenderung mempunyai pengetahuan yang lebih baik.

Selain faktor umur ibu faktor lain yang dapat mempengaruhi yaitu faktor pendidikan. Dalam hal ini prosentase tertinggi untuk pendidikan di Desa Bobang Kecamatan Semen Kabupaten Kediri adalah SD sejumlah 23 responden (66\%).Dalam hal ini kebanyakan responden berpendidikan terakhir SD dimana masih tergolong berpendidikan rendah. Pendidikan yang cenderung rendah akan sulit menerima informasi salah satunya tentang informasi kesehatan.

2. Pengetahuan Ibu Yang Memiliki Anak Usia 1-2 Tahun Setelah Diberikan Penyuluhan Tentang Penyapihan ASI

Berdasarkan hasil penelitian yang didapat pada tabel IV.2 responden pengetahuan ibu tentang penyapihan ASI setelah dilakukan penyuluhan, didapatkan bahwa 25 responden $(71,4)$ memiliki pengetahuan cukup, dan 10 responden $(28,6)$ memiliki pengetahuan baik. Hal tersebut telah membuktikan bahwa terdapat peningkatan pengetahuan ibu tentang penyapihan ASI sebelum dan setelah dilakukan penyuluhan.

Pengetahuan yang cukup pada ibu-ibu yang memiliki anak usia 1-2 tahun setelah 
diberikan penyuluhan tentang penyapihan ASI menunjukkan keberhasilan peneliti dalam memberikan penyuluhan. Hal ini menunjukkan bahwa informasi yang disampaikan dapat diterima dengan cukup baik oleh responden sehingga mampu menelaah dan mengerti dengan benar tentang materi yang diberikan oleh penyuluh.

Penyuluhan pada penelitian ini dilakukan dengan metode ceramah dan Tanya jawab. Sebelum diberi penyuluhan peneliti memberikan leaflet kepada responden. Penyuluhan dilakukan dengan cermat namun dibumbui dengan humor. Ini menjadi suatu cara agar penyuluhan lebih mengena bagi responden dan dapat menerima apa yang disampaikan dalam penyuluhan itu sendiri. Dalam memberikan penyuluhan peneliti harus mampu mengenal responden yang bertujuan responden bisa mengerti dan percaya kepada peneliti.

\section{Perbedaan Pengetahuan Ibu Yang Memiliki Anak Usia 1-2 Tahun Sebelum dan Setelah Diberikan Penyuluhan Tentang Penyapihan ASI}

Hasil uji statistic Wilcoxon Match

Pairs Test $\mathrm{Z}$ hitung sebesar 5,16 dengan tingkat kemaknaan 0,025 dan $\mathrm{z}$ tabel 1,96. Hal tersebut membuktikan bahwa nilai $Z$ hitung lebih besar dari nilai $\mathrm{Z}$ tabel ( 5,16> 1,96) sehingga $\mathrm{H}_{\mathrm{O}}$ ditolak $\mathrm{H}_{1}$ diterima.Adaperbedaan pengetahuan ibu yang memiliki anak usia 1-2 tahun sebelum dan setelah diberikan penyuluhan tentang penyapihan ASI. Dapat disimpulkan bahwa ada perbedaan pengetahuan ibu yang memiliki anak usia 1-2 tahun sebelum dan setelah diberikan penyuluhan tentang penyapihan ASI di Posyandu Desa Bobang Kecamatan Semen Kabupaten Kediri.

Perbedaan pengetahuan yang cukup setelah diberikan penyuluhan memperlihatkan bahwa responden cukup mampu menelaah dan menangkap informasi yang disampaikan melalui penyuluhan tersebut walaupun hasilnya tidak bisa langsung baik.Hal ini dikarenakan beberapa faktor salah satunya adalah faktor pendidikan.

\section{SIMPULAN}

1. Pengetahuan ibu yang memiliki anak usia 1-2 tahun sebelum diberikan penyuluhan tentang penyapihan ASI adalah kurang yaitu didapatkan 25 responden $(71,4 \%)$.

2. Pengetahuan ibu yang memiliki anak usia 1-2 tahun setelah diberikan penyuluhan tentang penyapihan ASI adalah cukup yaitu didapatkan 25 responden $(71,4 \%)$.

3. Berdasarkan hasil uji Wilcoxon Match Pairs Test membuktikan bahwa nilai $\mathrm{Z}$ hitung lebih besar dari nilai $\mathrm{Z}$ tabel ( 5,16> 1,96) sehingga $\mathrm{H}_{\mathrm{O}}$ ditolak $\mathrm{H}_{1}$ diterima.Dari sini dapat disimpulkan bahwa ada perbedaan pengetahuan ibu yang memiliki anak usia 1-2 tahun sebelum dan setelah diberikan penyuluhan Tentang Penyapihan ASI di Posyandu Desa Bobang Kecamatan Semen Kabupaten Kediri. 


\section{DAFTAR PUSTAKA}

Aryani, Wahyu. 2010. Merawat Bayi dan Ibu Hamil.Jakarta : Henzanura

Cox, Sue. 2006. Breastfeeding With Confidence. Jakarta: PT Alex Media Komputindo

Fitria, Ana. 2007. Panduan Lengkap Kesehatan Wanita. Yogyakarta: Gala Ilmu Semesta

Hasanah, Rina Ulfatul. 2012. Panduan Cerdas Kehamilan, Melahirkan, Menyusui \& Menyapih. Yogyakarta: Aulya Publishing

Hidayat, A. Aziz. 2010. Konsep dan Penerapan Metodologi Penelitian Ilmu Keperawatan. Jakarta: Salemba Medika

IBI.2003.50 Tahun Menyongsong Masa Depan. Jakarta: PP IBI

nusia. Yogyakarta: Nuha Medika
Kriatiyanasari, Weni.2009. ASI, Menyusui \& Sadari. Yogyakarta: Nuha Medika

Nakita. 2008. Panduan Tumbuh Kembang Anak. Jakarta: PT Penerbitan Sarana Bobo

Nursalam. 2011. Konsep dan Penerapan Metodologi Penelitian Ilmu Keperawatan. Jakarta: Salemba Medika.

Prasetyono, Dwi Sunar. 2009. Buku Pintar ASI Eksklusif. Yogyakarta: Diva Press

Roesli, Utami. 2005. Mengenal Asi Eksklusif. Jakarta: Trubus Agrawidya

Sears, William. 2007. Nutrisi dan Pemberian Makan Bayi. Jakarta: PT Serambi Ilmu Semesta

Utami, Prapti. 2006. Gizi dan Anak. Jakarta : PT. Agro Media Pustaka

Wawan dan Dewi. 2010. Pengetahuan, Sikap, Perilaku

$M a$ 